\title{
Capsaicin-sensitive sensory nerves, TRPV1 receptors and tachykinins play important roles in mast cell tryptase-induced arthritis and hyperalgesia
}

\author{
Zsuzsanna Helyes ${ }^{1 *}$, Éva Borbély ${ }^{1}$, Katalin Sándor ${ }^{1}$, Adrienn Markovics $^{1}$, Erika Pintér ${ }^{1}$, János Szolcsányi ${ }^{1}$, \\ John P Quinn², Jason J McDougall ${ }^{3}$
}

From 17th Scientific Symposium of the Austrian Pharmacological Society (APHAR). Joint meeting with the Hungarian Society of Experimental and Clinical Pharmacology (MFT)

Innsbruck, Austria. 29-30 September 2011

\section{Background}

Protease-activated receptors (PARs) are G protein-coupled receptors activated through proteolytic cleavage. They are localized on epithelial, endothelial and inflammatory cells, as well as on Transient Receptor Potential Vanilloid 1 (TRPV1) receptor-expressing capsaicin-sensitive sensory nerves. Tachykinins, such as substance $\mathrm{P}$ (SP) and neurokinin A (NKA) encoded by the TAC1 gene are released from these fibres and play an important role in inflammatory and nociceptive processes. We investigated the involvement of capsaicin-sensitive peptidergic afferents, TRPV1 ion channels and TAC1-encoded tachykinins in mast cell tryptase (MCT)-induced joint swelling, hyperalgesia and synovial microcirculation.

\section{Methods}

The natural PAR2 activator MCT $(20 \mu \mathrm{l}, 12 \mu \mathrm{g} / \mathrm{ml})$ was injected into the right tibiotarsal joint of mice. Pretreatment with high doses of the TRPV1 receptor agonist resiniferatoxin (RTX) was used to selectively inactivate capsaicin-sensitive peptidergic sensory nerves. TRPV1, TAC1 and neurokinin 1 receptor $\left(\mathrm{NK}_{1}\right)$ gene-deficient animals were also studied compared to their wild-type (WT) $\mathrm{C} 57 \mathrm{Bl} / 6$ counterparts. Knee diameter was measured with a digital micrometer, mechanonociceptive threshold with dynamic plantar aesthesiometry and spontaneous weight distribution with incapacitance

\footnotetext{
* Correspondence: zsuzsanna.helyes@aok.pte.hu

'Department of Pharmacology and Pharmacotherapy, Faculty of Medicine, University of Pécs, 7624 Pécs, Hungary

Full list of author information is available at the end of the article
}

tester throughout a 6-hour period. Synovial bloodflow in urethane-anaesthetized animals was determined by laser Doppler imaging. In these studies, MCT was applied topically on the joints.

\section{Results}

MCT-induced joint swelling and secondary hyperalgesia were significantly reduced in $\mathrm{TACl}^{-/-}$and $\mathrm{NK}_{1}{ }^{-1-}$ mice, but not in the other groups compared to WTs. Spontaneous weight distribution decreased by $10 \%$ on the injection site in response to MCT in WT mice, but not in any other groups. Synovial vasodilatation in response to topical MCT application was significantly smaller not only after the destruction of the capsaicin-sensitive afferents by RTX pretreatment, but also by the selective genetic deletion of the TRPV1 ion channels, but was not altered in TAC1 and $\mathrm{NK}_{1}$-deficient mice.

\section{Conclusions}

These data provide evidence that MCT-evoked acute oedema and hyperalgesia are mediated by tachykinins through $\mathrm{NK}_{1}$ receptor activation. The lack of difference observed in RTX-desensitized and TRPV1 ${ }^{-/-}$mice is likely to be explained by a counteracting effect of simultaneously released inhibitory peptides (e.g. somatostatin, endomorphins) from the same capsaicin-sensitive fibres. In contrast, these afferents and the TRPV1 receptors are essential in acute synovial vasodilatation, but tachykinis are not involved in this response.

(c) 2011 Helyes et al; licensee BioMed Central Ltd. This is an open access article distributed under the terms of the Creative Commons 


\section{Acknowledgements}

Supported by the Developing Competitiveness of Universities in the South Transdanubian Region (SROP-4.2.1.B-10/2/KONV-2010-0002), OTKA K73044 and ETT 03-380/2009.

\section{Author details}

'Department of Pharmacology and Pharmacotherapy, Faculty of Medicine, University of Pécs, 7624 Pécs, Hungary. ${ }^{2}$ School of Biomedical Sciences, Liverpool University, Liverpool L69 3BX, UK. ${ }^{3}$ Department of Physiology and

Pharmacology, University of Calgary, Calgary, Alberta, T2N 4N1, Canada.

Published: 5 September 2011

doi:10.1186/1471-2210-11-S2-A50

Cite this article as: Helyes et al:: Capsaicin-sensitive sensory nerves, TRPV1 receptors and tachykinins play important roles in mast cell tryptase-induced arthritis and hyperalgesia. BMC Pharmacology 201111 (Suppl 2):A50.

\section{Submit your next manuscript to BioMed Central} and take full advantage of:

- Convenient online submission

- Thorough peer review

- No space constraints or color figure charges

- Immediate publication on acceptance

- Inclusion in PubMed, CAS, Scopus and Google Scholar

- Research which is freely available for redistribution

Submit your manuscript at www.biomedcentral.com/submit 